\title{
Velum Interpositum Cistern
}

National Cancer Institute

\section{Source}

National Cancer Institute. Velum Interpositum Cistern. NCI Thesaurus. Code C33857.

A supratentorial cistern of the brain that is located inferior to the splenium of the corpus

collosum, between the thalamus and the fornix. 